\title{
Effect of temperature changes on the cercarial-shedding rate of two trematodes
}

\author{
Cecilia L. Achiorno \& Sergio R. Martorelli
}

Centro de Estudios Parasitológicos y de Vectores, Consejo Nacional de Investigaciones Científicas y Técnicas - Universidad Nacional de La Plata (CCT La Plata CONICET, UNLP). Boulevard 120 S/N e/61 y 62 (B1902CHX) La Plata, Buenos Aires, Argentina. (achiorno@cepave.edu.ar; sergio@cepave.edu.ar)

ABSTRACT. Since temperature is a key condition in the initiation of cercarial emergence, the objective of the work reported here was to evaluate the effect of that variable on the shedding of two morphologic and taxonomic types of cercariae. Bioassays were accordingly performed with snails naturally infected with either monostome or pleurolophocercous cercariae because those two cercarial types were found to be the most prevalent in the environment under study. The snails were placed in 6-ml circular plastic dishes with soft plastic stoppers containing $3 \mathrm{ml}$ of reconstituted water and then sequentially exposed for $24 \mathrm{~h}$ to a $14: 10$-h light:dark cycle at 20,25 , or $30^{\circ} \mathrm{C}$. The data were analyzed at a significance level of $\mathrm{p}<0.05$ by means of the InfoStat program. The optimum temperature for cercarial emergence was typically in the range of $25^{\circ} \mathrm{C}$ and decreased significantly at $30{ }^{\circ} \mathrm{C}$. We observed no significant difference in the number of cercariae emerging between the two morphologic types.

KEYWORDS. Parasites, cercarial emergence, freshwater, temperature, bioassay.

RESUMEN. Efecto de cambios en la temperatura sobre la emergencia de cercarías de dos trematodes. Considerando que la temperatura es un factor clave en la emergencia de cercarias, el objetivo de este trabajo fue evaluar el efecto de ésta variable sobre la emergencia de dos tipos morfológicos de cercarias. Los bioensayos se realizaron con caracoles naturalmente infectados con cercarias de los tipos monostoma o pleurolofocerca, debido a que estos dos tipos fueron los más prevalentes en el ambiente en estudio. Los caracoles fueron ubicados en cápsulas plásticas de $6 \mathrm{ml}$ conteniendo $3 \mathrm{ml}$ de agua reconstituida, y entonces fueron secuencialmente expuestos por $24 \mathrm{~h}$ con un ciclo $14: 10 \mathrm{~h}$ luz:oscuridad a 20,25 y $30^{\circ} \mathrm{C}$. Los datos fueron analizados a un nivel de significación de $\mathrm{p}<0.05$ con el programa InfoStat. Los resultados mostraron que la temperatura óptima de la emergencia de cercarias estuvo en el rango de $25^{\circ} \mathrm{C}$, y disminuyó significativamente a $30^{\circ} \mathrm{C}$. Se observó también que no existía diferencia significativa en el número de cercarias emergentes entre los dos tipos morfológicos.

PALABRAS-CLAVE. Parásitos, emergencia de cercarias, agua dulce, temperatura, bioensayo.

Parasites are one of the main ecologic groups involved in the organization of faunal communities (THOMAs et al., 2006) and therefore data on the dynamics of the different parasitic developmental stages is fundamental. For example, cercarial emergence from the first intermediate host is a key phase in the reproductive success of trematodes; and this step is directly related to the life-span of the cercariae (at $c a .24 \mathrm{~h}$ ), within which period emergence needs to occur at an optimal time (Esch et al., KARVONEN et al., 2004). Therefore, a determination of the environmental conditions that influence cercarial emergence becomes imperative for gaining an understanding of trematode transmission since the latter often begins in response to abiotic changes. Temperature, in addition to light and water conditions, is one of the main drivers of cercarial emergence through, either directly or indirectly, an acceleration of both the maturation and the liberation of the cercariae. Cercarial emergence from the snail host can be stimulated by a change in temperature, with the effect of this influence being often trematode-specific (MOURITSEN, 2002; FINGERUT et al., 2003;
Ahmed et al., 2006; Poulin, 2006; KoprivniKar \& Poulin, 2009a,b; Vignoles et al., 2014). Consequently, in order to initiate ecological studies on a given trematode group, a determination of the optimum temperature must be one of the first steps to be carried out before other parameters can be reasonably investigated.

In Argentina the evaluation of freshwater trematodes has focused on morphological descriptions and on the study of the life cycles of different species, whereas considerations of environmental variables affecting cercarial emergence have been restricted principally to the influence of light for example, the number of cercariae emerging per h after exposure to the light (MARTORELli, 1984, 1989, 1990; OstrowsKi De NuÑEZ, 1995; OstrowsKi DE NuÑEZ et al., 2003; Davies \& Ostrowski De NuÑEZ, 2012; FernandeZ et al., 2013a,b). According to several authors, cercarial emergence from the snail is stimulated by light by means of a larval positive phototropism occurring at the time when the snail tissues emerge - a timing that is, in turn, governed by the circadian light-dark cycle along with temperature 
differences as Zeitgebers (MORLEY et al., 2010).

Since the environmental characteristics promoting the development of trematode life cycles within this region are still not understood, a determination of the optimum temperature for the progression of these organisms through the different stages of their life cycle becomes crucial for an elucidation of their dynamics. The objective of the experiments reported here was thus to evaluate the effect of temperature on the emergence of two cercarial morphologic types, with an aim at determining both the optimal temperature and whether or not significant differences in the degree of cercarial shedding resulted between the two types.

\section{MATERIALS AND METHODS}

We examined the two cercarial morphologic types found to be the most common in prior screenings of infected snails, the monostome and the pleurolophocercous (SCHELL, 1985; Martorelli \& Etchegoin, 1996; Etchegoin \& MARTORELLI, 1998). Monostome cercariae typically have three eyespots, lack a ventral sucker, and contain abundant cystogenous glands along with dorsal adhesive organs. The pleurolophocercous cercariae have a tail with anterior cuticular thickening and lateral and/or dorsoventral fins and/or fin folds. These two cercarial types belong to the Notocotylidae and Cryptogonimidae families, respectively. The life cycle of these trematode types has not yet been elucidated, but both use the snail Heleobia parchappei (Orbigny, 1835) as the first intermediate host.

The bioassays were made with naturally infected H. parchappei because the latter are more suitable for the investigation of the levels of cercarial emergence (MORLEY et al., 2010). Approximately 1,300 snail individuals were collected from the Martín Stream (Buenos Aires province, Argentina) during December 2014. The mean annual temperature for this location is $16.2^{\circ} \mathrm{C}$, with January being the hottest month (mean temperature, $22.8^{\circ} \mathrm{C}$ ) and July the coldest (mean temperature, $9.9^{\circ} \mathrm{C}$; http://www.estadistica. laplata.gov.ar/paginas/climasueloLP.htm).

The snails were collected randomly by hand and after transportation to the laboratory were kept in 2-L glass containers filled with reconstituted water (hardness $108 \mathrm{mg}$ $\mathrm{Ca} / \mathrm{L})$ at an ambient temperature of $23 \pm 2{ }^{\circ} \mathrm{C}$ and in the dark and fed with flaked fish food.

To screen for infected snails for use in the bioassays, individuals from six groups of 240 snails each were placed in 6-ml wells of microtest plates containing $3 \mathrm{ml}$ of reconstituted water and exposed to light stimulation before being examined periodically for cercarial emergence. Individuals found to be infected were then transferred to 2-L glass containers under the same conditions as described above. For the bioassays 10 snails each parasitized by either cercarial type were used for the abrupt-exposure test, and were placed in 6-ml wells of microtest plates containing $3 \mathrm{ml}$ of reconstituted water.

To evaluate the effect of three temperatures, 20, 25, and $30{ }^{\circ} \mathrm{C}$ on the emergence of cercariae, the experiments were conducted separately for the two cercarial morphologic types in the form of abrupt bioassays ( $c f$. Fig. 1). The experiments were initiated in an incubator set at $20^{\circ} \mathrm{C}$ with a 14:10-h light:dark cycle, where all the plates were kept at this temperature for $24 \mathrm{~h}$. A closed thermostatic bath used within the incubator was set at the next temperature (Koprivnikar \& Poulin, 2009a). After $24 \mathrm{~h}$ at $20{ }^{\circ} \mathrm{C}$, all the snails were individually transferred into new dishes (prewarmed at $25^{\circ} \mathrm{C}$ within the thermostatic bath) for abrupt exposure before being placed in the incubator now reset at $25^{\circ} \mathrm{C}$. The cercariae remaining in the dishes at the lower temperature were then directly counted after transfer of the snails to the new temperature. The thermostatic bath was then set at $30{ }^{\circ} \mathrm{C}$. After $24 \mathrm{~h}$ at $25{ }^{\circ} \mathrm{C}$ in the incubator, all the snails were then individually transferred into new dishes (prewarmed to $30{ }^{\circ} \mathrm{C}$ within the thermostatic bath) for a second abrupt exposure before being placed in the incubator reset at $30{ }^{\circ} \mathrm{C}$. The cercariae remaining in the dishes at the lower temperature $\left(25^{\circ} \mathrm{C}\right)$ were then counted after transfer of the snails to the new temperature. At the end of the assay, the cercariae remaining in the wells of the third set of dishes were counted and the snails measured with calipers before being returned to their original wells. The protocol followed in this experiment was based on the work of KOPRIVNIKAR \& Poulin (2009a) and previous bioassays performed by us to maximize the methodology.

Statistical analyses were initially conducted for each separate bioassay in order to determine the differences between the cercarial numbers with respect to temperature. The normality of cercarial-emergence values was analyzed by the Shapiro-Wilk test. When that distribution was nonnormal, the Kruskal-Wallis test was used to establish the optimal temperature.

The second step - expressing the mean values registered for the total numbers of emerged cercariae per morphologic type per day - involved comparisons made between the two cercarial types (i.e., monostome and

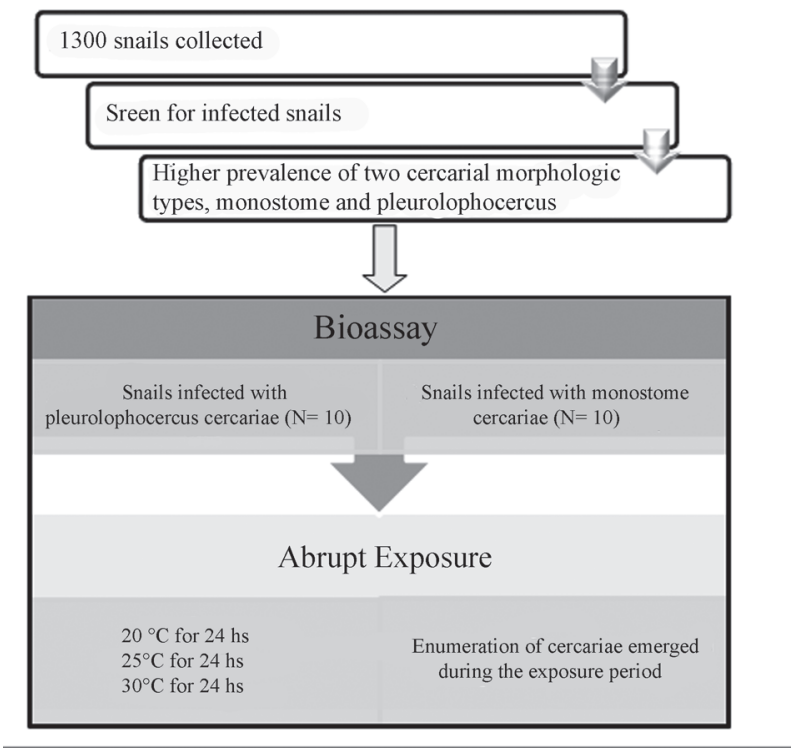

Fig. 1. Flow diagram of experimental procedure for cercariae emergence assays. 
pleurolophocercous) for each temperature. When comparisons were made, the data were subjected to a Wilcoxon test because the data distribution was nonnormal.

As snail size could potentially affect the number of cercariae emerging (KoPRIVNIKAR \& POULIN 2009a,b), a correlation analysis was also made by calculating the Spearman coefficient. Because, however, that last test indicated that the parameters snail size and cercarial number emerging were not correlated, no further transformations of the data were performed.

All statistical analyses were carried out with InfoStat software (http://www.infostat.com.ar) at a significance level of 0.05 .

\section{RESULTS}

The Fig. 2 summarizes the results of the experiments testing cercarial emergence as a function of ambient temperature. The optimum temperature for the shedding of the monostome type appeared to be from $20^{\circ} \mathrm{C}$ (at a mean value of $30.0 \pm 25.7$ cercariae emerging in $24 \mathrm{~h}$ ) to $25^{\circ} \mathrm{C}$ (at a mean value of $31.5 \pm 41.2$ individuals per $24 \mathrm{~h}$ ) since the emergence diminished markedly at $30^{\circ} \mathrm{C}$ (down to a mean value of only $6.80 \pm 9.11$ ). Likewise, with the pleurolophocercous cercariae, the optimum temperature was $25^{\circ} \mathrm{C}$ (at a mean value of $20.0 \pm 10.6$ individuals per $24 \mathrm{~h}$ ) in contrast to a lower average shedding at $20^{\circ} \mathrm{C}$ (at a mean value of $12.0 \pm 15.9$ ) and a still lower level at $30^{\circ} \mathrm{C}$ (at a mean value of only $3.30 \pm 9.41$. Accordingly, the statistical treatments of the data for both cercarial types verified that the emergences at $30^{\circ} \mathrm{C}$ were significantly lower than those at either of the two lower temperatures - with $\mathrm{H}$ values for the two respective trematode types at $7.88(\mathrm{p}=0.0192)$ and $10.4(\mathrm{p}=0.0046)$.

From the data for the average daily cercarial emergence shown in Fig. 2, the maximum values occurred with the shedding from snails exposed to a temperature of $25^{\circ} \mathrm{C}$ while the minima were recorded pleurolophocercous $(3.30 \pm 9.41)$ after an abrupt shift to $30^{\circ} \mathrm{C}$ with both types of trematode cercariae. From these differences in the data, we might have concluded prima facie that emergence was greater with the monostome cercariae at both 25 and $30^{\circ} \mathrm{C}$;

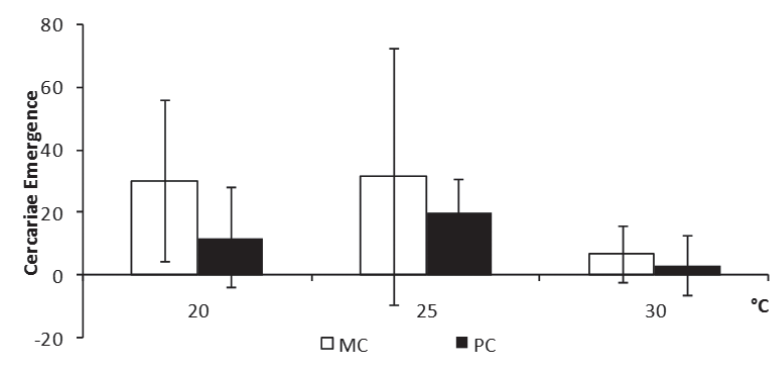

Fig. 2. Average daily emergence of cercariae at three temperatures (MC, monostome cercariae; PE, pleurolophocercous cercariae). The bars correspond to the standard deviation. In the figure the ordinate indicates the mean number of cercariae shed per $24 \mathrm{~h}$ at each of the temperatures shown on the abscissa. but since the only comparison manifesting a statistically significant difference in emergence between the two cercarial types occurred at the basal temperature of $20^{\circ} \mathrm{C}$, statistical analysis of the data (Tab. I) indicated that cercarial emergence in general was not unilaterally greater for the monostome than for the pleurolophocercous trematodes.

Tab. I. Comparison of the shed data between the monostome and pleurolophocercous morphologic cercarial types at the different temperatures tested $(*$, significantly different; NS, not significantly different)

\begin{tabular}{cccc}
\hline Temperature & $\mathrm{p}$ value & Test & Evaluation \\
\hline 20 & 0.0444 & Wilcoxon & $*$ \\
25 & 0.9698 & Wilcoxon & NS \\
30 & 0.0822 & Wilcoxon & NS \\
\hline
\end{tabular}

\section{DISCUSSION}

The ambient temperature - recognized as one of the conditions that influences snail-trematode interactions - could have different effects on either the host or the parasite. The developmental state of trematodes in mollusks is influenced by temperature since an increase leads to a reduction in the cercarial developmental time (MORLEY et al., 2010). Temperature - either directly or indirectly - also triggers cercarial release (KoPRIVNIKAR \& PoulIn, 2009b). The results of our study demonstrated that, as expected, the emergence of cercariae from snails infected with the monostome and pleurolophocercous cercarial types was significantly affected by temperature and indicated an optimal temperature for the emergence of those types as being within the range of $25^{\circ} \mathrm{C}$.

Even though emergence was somewhat greater with the monostome than with the pleurolophocercous cercariae, that difference was statistically significant at only an ambient temperature of $20^{\circ} \mathrm{C}$. At that temperature the monostome cercariae would presumably have a higher probability of emergence for encysting within the environment than the pleurolophocercous.

The results upon testing the effect of temperature on the emergence of monostome and pleurolophocercous cercariae in the present work were similar to those reported for other trematode groups (Tab. II), although a direct comparison of these results with those obtained by other investigators was difficult to realize: first because the temperatures encountered in the bioassays described in the literature were often not the same and second since the parameters evaluated by other authors did not permit a conclusive comparison with the conditions examined by us - namely, the protocol followed, the data obtained with respect to the time of exposure to the experimental conditions, and especially the form of expression of the values (i.e., as the maximum, minimum, and mean emergence along with the range). The following two examples illustrate the wide variability in the expression of experimental details and results that occurs within the literature (for these examples and three others $c f$. Tab. II): emergence per h (SCHMIDT \& FrIed, 1996; Tab. II [2]) or "daily emergence was subsequently observed on 3 variable days over a 6-day period at each temperature" (MORLEY et al., 2010; Tab. II [5]). For their part, certain investigators used 
Tab. II. Reports of cercariae emergence at temperatures comparable to those used in the present work [Refs. (References): 1, Lo \& LEE, 1996; 2, SCHMIDT \& Fried, 1996; 3, Lyholt \& Buchmann, 1996; 4, Terhune et al., 2002; 5, Morley et al., 2010].

\begin{tabular}{|c|c|c|c|c|c|c|}
\hline Temperature $\left({ }^{\circ} \mathrm{C}\right)$ & Species & & Emergence & & Observations & Refs. \\
\hline & & Average & Maximum & Range & & \\
\hline 25 & Centrocestus formosanus & 1.64 & 63,400 & - & Emergence/day & 1 \\
\hline 12 & Echinostoma trivolvis & 13 & - & - & Emergence/h & 2 \\
\hline $22-24$ & & 29 & - & - & & \\
\hline 37 & & 82 & - & - & & \\
\hline 20 & Diplostomum spathaceum & - & 58,000 & - & Cercaria/snail/day & 3 \\
\hline 25 & Bolbophorus confusus & - & - & $86.3-350$ & Average number of cercariae shed over a 24 -h period & 4 \\
\hline 21 & $\begin{array}{l}\text { Echinoparyphium } \\
\text { recurvatum }\end{array}$ & - & - & $741-2,214$ & $\begin{array}{l}\text { Each group of } 3 \text { snails was acclimatized to a different } \\
\text { temperature for } 3 \text { days. Daily emergence was } \\
\text { subsequently observed on } 3 \text { variable days over a 6-day } \\
\text { period at each temperature. }\end{array}$ & 5 \\
\hline 25 & & - & - & $798-1,752$ & & \\
\hline
\end{tabular}

a gradual exposure of the snails to a change in temperature (Lo \& Lee, 1996; Tab. II [1]; LyHolt \& BuchmanN, 1996; Tab. II [3]; Terhune et al., 2002; Tab. II [4]; Morley et al., 2007, 2010), while others exposed the host individuals abruptly to different temperatures (SCHMIDT \& FRIED, 1996; Fried et al., 2002; KoprivNiKar \& POULIN, 2009a; VignOles et al., 2014; PAull et al., 2015).

Despite differences in the expression of results or the protocol for evaluating the effect of temperature, the examples listed in Tab. II show that cercarial emergence usually increases with elevations in temperature up to an optimum level. In addition to the those studies, we would cite results obtained by Vignoles et al. (2014) with the Fasciola hepatica - Galba trucatula model since with that paradigm a decrease in temperature by an abrupt change into colder water, in fact, stimulated emergence. By contrast, MorLey et al. (2010) found that the shedding of Echinoparyphium recurvatum, after first increasing with elevations in temperature, stabilized within the range of 17 to $25{ }^{\circ} \mathrm{C}$, and after that plateau decreased at temperatures above $25^{\circ} \mathrm{C}$. This latter decline in emergence is consistent with our own observations but differs from the findings of SCHMIDT \& FRIED (1996), whose results coincided with those of Poulin (2006) - namely, that "an increase of a few degrees in environmental temperatures should lead to marked increases in cercarial emergence from the snail's first intermediate hosts", but, we must advise that these studies have been indicated by MoRLEY \& LEwIS (2013) to be likely associated with inadequate acclimation of snails to experimental conditions. Our results and the comparable findings of MORLEY et al. (2010) would indicate that the emergence and resulting abundance of freshwater cercariae in temperate climates are not necessarily increased by an elevation in temperature above $25^{\circ} \mathrm{C}$.

This conclusion coincides with the proposal in the review of MORLEY \& LEWIS (2013) that midlatitude species (i.e., from between 36 and $60^{\circ}$ ), such as those studied here, exhibit an optimum temperature of emergence from 15 to 25 ${ }^{\circ} \mathrm{C}$. Therefore, from the results of the present study and the observations of the earlier work cited above, an elevation in ambient temperature cannot be said to enhance cercarial shedding in general; rather, the effect of temperature on emergence is a trematode-specific phenomenon.

Finally, since information on the influence of temperature is needed to gain a better understanding of cercarial emergence in Argentina, the results reported here will provide valuable data on this question since these findings enable a greater understanding of the ecology of the South-American trematodes of temperate climates. Because temperature would be one of the main abiotic conditions affecting cercarial shedding, the use of an optimum temperature with these trematode types will facilitate further studies for determining the effect of additional influences - both environmental and anthropic - on the life cycle of these parasites.

Acknowledgements. We thank Jorge Barneche for his help during fieldwork. The CONICET provided financial support. Dr. Donald F. Haggerty, a retired academic career investigator and native English speaker, translated certain portions of the manuscript from the original Spanish and edited the final version.

\section{REFERENCES}

Ahmed, A.; Ibrahim, N. \& Idris, M. 2006. Laboratory Studies on the Prevalence and Cercarial Rhythms of Trematodes from Bulinus truncatus and Biomphalaria pfeifferi Snails from Khartoum State, Sudan. Sultan Qaboos University Medical Journal 6(2):65-69.

Davies, D. \& Ostrowski de Nuñez, M. 2012. The Life Cycle of Australapatemon magnacetabulum (Digenea: Strigeidae) from Northwestern Argentina. Journal of Parasitology 98(4):778-783.

Esch G. W.; Curtis, L. A. \& Barger, M. A. 2001. A perspective on the ecology of trematode communities in snails. Parasitology 123:57-75.

Etchegoin, J. A. \& Martorelli, S. R H. 1998. Cercarias de la superfamilia Opistorchioidea en Heleobia conexa (Mollusca: Hydrobiidae) de la albufera de Mar Chiquita. Neotropica 4(111-112):91-50

Fernandez, M.; Hamann, M. \& KeHer, A. 2013. Biology of Kalipharynx sp. (Trematoda: Digenea) metacercariae in Biomphalaria (Gasteropoda: Planorbidae) from Northeastern Argentina. International Journal of Tropical Biology and Conservation 61(4):1647-1656.

Fernandez, M.; Hamann, M. \& Ostrowski DE NuÑEz, M. 2013. Larval trematodes of Biomphalaria straminea (Mollusca: Planorbidae) in a ricefield in Corrientes Province, Argentina. Revista Mexicana de Biodiversidad 84(3):756-764.

Fingerut, J.; Zimmer, C. \& Zimmer, R. 2003. Patterns and processes of larval emergence in an estuarine parasite system. The Biological Bulletin 205:110-120. 
Fried, B.; LAterra, R. \& Kim, Y. 2002. Emergence of cercariae of Echinostoma caproni and Schistosoma mansoni from Biomphalaria glabrata under different laboratory conditions. Journal of Helminthology 76:369-371.

Karvonen, A.; Kirsi, S., Hudson, P. J. \& Valtonen, E. T. 2004. Patterns of cercarial production from Diplostomum spathaceum: terminal investment or bet hedging? Parasitology 129(01):87-92.

Koprivnikar, J. \& Poulin, R. 2009a. Effects of temperature, salinity, and water level on the emergence of marine cercariae. Parasitology Research 105:957-965

Koprivnikar, J. \& Poulin, R. 2009b. Interspecific and Intraspecific Variation in Cercariae Release. Journal of Parasitology 95(1):14-19.

Lo, C. \& LeE, K. 1996. Pattern of Emergence and the Effects of Temperature and Light on the Emergence and Survival of Heterophyid Cercariae (Centrocestus formosanus and Haplorchis pumilio). The Journal of Parasitology 82(2):347-350.

Lyholt, H. \& Buchmann, K. 1996. Diplostomum spathaceum: effects of temperature and light on cercarial shedding and infection of rainbow trout. Diseases of Aquatic Organisms 25:169-173.

Martorelli, S. 1984. Sobre una cercaria de la familia Schistosomatidae (Digenea) parasita de Chilina gibbosa Sowerby, 1841 en el lago Pellegrini, provincia de Rio Negro, República Argentina. Neotropica 30(83):97-106.

Martorelli, S. 1989. Estudios parasitologicos en la albufera de Mar Chiquita, provincia de Buenos Aires, República Argentina. II: Cercarias (Digenea) parasitas de Heleobia conexa (Mollusca: Hydrobiidae), pertenecientes a las familias Schistosomatidae, Haploporidae y Homalometridae. Neotropica 35(94):81-90.

Martorelli, S. 1990. Estudios parasitologicos en la albufera de Mar Chiquita, provincia de Buenos Aires, República Argentina. III: Sobre dos cercarias parasitas de Heleobia conexa (Mollusca: Hydrobiidae) pertenecientes a la superfamilia Echinostomatoidea. Neotropica 36(95):5-12.

Martorelli, S. H. \& Etchegoin, J. A. 1996. Cercarias de la superfamilia Opistorchioidea en Heleobia conexa (Mollusca: Hydrobiidae) de la albufera de Mar Chiquita. Neotropica 42(107-108):61-67.

Morley, N.; AdAm, M. \& Lewis, J. 2007. The effects of temperature on the distribution and establishment of Echinoparyphium recurvatum metacercariae in Lymnaea peregra. Journal of Helminthology 81:311315 .
Morley, N.; Adam, M. \& Lewis, J. 2010. The effects of host size and temperature on the emergence of Echinoparyphium recurvatum cercariae from Lymnaea peregra under natural light conditions. Journal of Helminthology 84:317-26.

Morley, N. J. \& LeWIS J.W. 2013. Thermodynamics of cercarial development and emergence in trematodes. Parasitology 40(10):1211-1224.

Mouristen, K. 2002. The Hydrobiaulvae-Maritrema subdolum association: influence of temperature, salinity, light, water-pressure and secondary host exudates on cercarial emergence and longevity. Journal of Helminthology 76:341-347.

Ostrowski DE NuÑEz, M. 1995. Life history of Pygidiopsis crassus n. sp. (Trematoda, Digenea, Heterophyidae) in the neotropical region. Memórias do Instituto Oswaldo Cruz 90(1):13-19.

Ostrowski de Nuñez, M.; Spatz, L. \& GonzÁlez Cappa, S. 2003. New Intermediate Hosts in the Life Cycle of Zygocotylelunata in South America. Journal of Parasitology 89(1):193-194.

Paull, S.; Raffel, T.; Lafonte, B. \& Johnson, P. 2015. How temperature shifts affect parasite production: testing the roles of thermal stress and acclimation. Functional Ecology 29:941-950.

Poulin, R. 2006. Global warming and temperature-mediated increases in cercarial emergence in trematode parasites. Parasitology 132:143-151.

SCHELl, S. C. 1985. Handbook of trematodes of North America, North of Mexico. Moscow, University Press Idaho. 263p.

Schmidt, K. \& FRIED, B. 1996. Emergence of Cercariae of Echinostoma trivolvis from Helisoma trivolvis under Different Conditions. The Journal of Parasitology 82(4):674-676.

Terhune, J.; Wise, D. \& Khoo, L. 2002. Bolbophorus confusus Infections in Channel Catfish in Northwestern Mississippi and Effects of Water Temperature on Emergence of Cercariae from Infected Snails. North American Journal of Aquaculture 64(1):70-74.

Thomas, F.; Renaud, F. \& GuÉGAn J-F. 2006. Parasitism \& Ecosystems. Oxford, Oxford University Press. 221p.

Vignoles, P.; Titi, A.; Rondelaud, D.; Mekroud, A. \& Dreyfuss, G. 2014. Fasciola hepatica: effect of the natural light level on cercarial emergence from temperature-challenged Galba truncatula. Parasite21(8), doi: 10.1051/parasite/2014009. 